\title{
Research on the Innovation of College Student Management in Big Data Era
}

\author{
Wenli Chen \\ City College of Dongguan University of Technology \\ Dongguan, China 523419
}

\begin{abstract}
The big data era has brought both rare opportunities and challenges for further enhancement and improvement of college student management. Through the application of big data technology, the innovation of college student management has become an important means to improve the management level of college students. The primary party organization of students in colleges and universities can strengthen students' ideological education, establish an early warning mechanism, carry out accurate funding, and strengthen the management on employment and entrepreneurship education through big data technology, thus promoting the innovation and healthy development of student management.
\end{abstract}

Keywords - big data; colleges and universities; college student management

\section{INTRODUCTION}

Entering big data era, "huge amount of data are becoming a resource and a production factor, and penetrate into various fields. Possessing big data ability, that is, adept in aggregating information and making effective use of data, will bring endless innovations, and it represents a kind of productivity in a sense". [1] Under such a background, college student management must accurately grasp the development of the times, fully recognize the value of data, seize the opportunity, and create a new situation for college student management.

\section{NEW OPPORTUNITIES FOR COLLEGE STUDENT MANAGEMENT IN BIG DATA ERA}

\section{A. Big Data Technology Can Provide Decision-making Basis for College Student Management}

With the wide application of big data technology, all walks of life deeply explore and analyze all aspects of people's thoughts and deeds by means of data analysis, so as to make scientific decisions. A special column in New York Times in February 2012 said, "big data" era had already arrived. In business, economy and other fields, decisions will increasingly be made based on data rather than based on experience and intuition. College student management involves many functional departments and the involved information is complex and diverse. The various types of information and data are intricate and it is difficult to use traditional and simple way for statistics and description. Due to the application of big data technology in student management, information will be analyzed, sorted and summarized in a scientific and reasonable manner, and finally an intuitive analysis report will be formed, which will provide a basis for decision-making of college student management.

\section{B. Big Data Technology Helps to Master the Ideological Trend of College Students}

To master the ideological trend of college students is the basic work for college student management, as well as a precondition for effective implementation of various student management works. For a long time, college students' affairs office masters the ideological trend of college students in the forms of individual conversation, questionnaire, class meetings and seminar, supplemented by browsing students' Weibo, friend circle, QQ space, etc. However, because of a variety of reasons, some students may deliberately hide their true thoughts. Therefore, even though a lot of manpower and resources are spent, the real thoughts and actual situations of students still cannot be obtained, which brings hidden dangers to college student management. The application of big data technology is conducive to addressing this problem, and the reason is that big data platform can obtain huge daily data information, and process and analyze it. Through this information, the college student management department can grasp the current situation of student party members and their thoughts and behavior situation for a long time, so as to predict the development trend of the students' thoughts, and to form a practical college student management work plan on this basis.

\section{Big Data Technology Helps to Establish an Effective Mechanism for Student Management}

To strengthen college student management, we should attach importance to establishing scientific systems and mechanisms and improving working methods. First of all, we need to evaluate the existing system and find out the impact factors of each link. In the past, limited by technical conditions, only a small number of major factors were included in the assessment. After the wide application of big data technology, a large number of relevant impact factor data can be collected, so that the effects of various systems and activities can be comprehensively and objectively evaluated, and deficiencies and details of a specific link also can be searched. Moreover, through the application of big data technology, we can also grasp the students' usual behavior, practical concerns and online activities, and analyze the characteristics of college students' thoughts and behavior, so as to test the effectiveness 
of the college student management and promote the continuous improvement of college student management mechanism.

\section{Big Data Technology Helps to Improve the Accuracy and Scientificity of College Student Management}

In colleges and universities, because of many functional departments involved in the student management work, it is inevitable that different departments have their understanding and idea on student management work. Moreover, due to different service level of departments for students, it will cause corresponding deviation on student management work. Based on big data thinking, the formed big data resource service platform grabs student information such as academic achievement, participation in the second classroom activities, daily consumption and health data by means of big data technology, and integrates them, so as to form an information report showing the students' growth track and life trace. These data reports and background statistical data help functional departments in colleges and universities to master students' overall situation and largely overcome the dogmatic principles and subjective judgments. They also help us to adopt targeted student management strategies, thus building a humanized and scientific management model.

\section{The Challenges of College StUdent MANAGEMENT IN BIG DATA ERA}

\section{A. The Environment for College Student Management Has Changed}

The environment for college student management has been impacted by new media in big data era, so the relatively single and closed situation becomes more complex and open. Under this environment, college students can easily access all kinds of information, including negative and false information. This information will directly impact some students' world outlook, outlook on life and values, and shake their ideals and beliefs, leading to the emergence of negative thoughts and weak political thoughts. Next, in the network times, the students after 90 s extremely rely on the Internet and cannot be separated from the cell phone. They keep the social software online for 24 hours, like to look for excitement in the virtual world, seek sense of identity on the Internet and make friendly contacts on social software, but they ignore the interpersonal communication. Therefore, it makes the student organization become less attractive to students and sincere communication are gradually reduced within student organization, and students lower trust for their instructor and it is difficult for them to communication openly. Many student activities become a mere formality, and the influence, centripetal force and cohesiveness of college student organizations have been weakened.

\section{B. Large Data Technical Information Collection Is Difficult}

To put big data application of college students into practice, we must have massive, complex and time-efficient data, as well as a platform that can analyze data and discover the value of data. Firstly, we must collect and analyze all student-related information such as students' personal basic information, family information, academic achievement, daily performance information, rewards and punishments, integrity files and psychological files. Nevertheless, such information commonly appears in the students' paper file, and the paper file is often incomplete and not updated in time, which will result in inaccurate information and poor reference. Second, we must integrate the relevant information data in the existing information management system for college students, university website platform, university office automation system, and various second classroom systems. Third, at present, all colleges and universities have not formed a unified data standard and data management document. It is inevitable that the data statistics will be increased and data analysis will be complicated because of the inconsistent statistical standards. Undoubtedly, all of these bring many difficulties to information collection. Moreover, both data collection and platform construction require a lot of manpower and material resources and excellent technology, which is a big challenge for various functional departments and related staff in colleges and universities.

\section{There Are Hidden Dangers in Big Data Information Security Management}

In addition to information collection, information security is also a big problem. The generation and application of big data is inseparable from the network. The openness of the network itself may bring great harms to the database, website and management system. Once the internal system suffers from malicious invasion from hackers and Trojan virus, students' personal information and universities' confidential information will be at risk of disclosure. Therefore, how to ensure the security of information management is a big challenge for college student management.

\section{Big Data Technology Is Temporarily Difficult to Meet Individual Needs}

In big data era, people's living standard has been significantly improved, and the requirements have been promoted accordingly. The need for personalization is stronger, and the characteristics of personalization are more obvious. Apart from the implementation of traditional unified standard, integrated management, and strict management, college student management also can sort out, summarize and analyze information with small amount, similar categories and formed structure by using the existing technical means. However, nowadays, it is difficult to complete the collection, storage, analysis, and visualization presentation of big data, to widely use big data analysis technology, and to invest a large amount of energy and financial technology to analyze students' individual needs in learning, employment and psychology and implement personalized management.

\section{EFFECTIVE PATH OF INNOVATION IN COLLEGE STUDENT MANAGEMENT IN BIG DATA ERA}

\section{A. Strengthening Students' Ideological Education by Using Big Data Technology}

In big data era, the Internet + technology makes student education no longer attach to a face-to-face manner in a specific time. We can accomplish the work related to education by virtual means through new media technology at 
any time, and combine "online" and "offline" forms, to vividly enhance the education and guidance of students. "Offline" form includes traditional lectures, presentations, etc. We can enhance the interaction with new media to stimulate students' enthusiasm to participate in traditional activities. In terms of "online" form, we can first establish a WeChat platform official account for student organization, and send messages and information to the fans who subscribe for information every day to enhance its publicity and influence. We establish QQ group and WeChat group within the organization to realize instant and effective sharing of resources. We also establish and improve the official Weibo for publicity, pay attention to students' thoughts through their microblog, and deal with abnormal problems in time. Moreover, relying on the actual organization, we establish various "network communities" for student organization, and guide students to actively participate in activities, to achieve the purpose of education management, resource sharing and team cooperation.

\section{B. Establishing an Early Warning Mechanism by Using Big Data Technology}

Based on large data technology, a large data resource service platform will be formed to record students' daily information, attendance records, academic achievement, mental health and physical health, fully utilize data for correlation analysis, and find the internal relations between students' various information. For students who fail in the exam and also have serious absenteeism, we will find out the corresponding reasons based on their relevant information, and provide early warnings to them, to reduce student punishment, retention and dropout. For students who have great psychological changes, we identify the possible causes based on their mental health reports and related information, and offer psychological persuasion to students, to reduce the probability of students' mental illness. For students' sick leave, hospital reports and other daily life data, we will conduct a health education for them, encourage them to exercise more, and establish good habits, thus establishing a humanized management mode and education mode.

\section{Carrying out Accurate Funding by Using Big Data Technology}

Currently, the proportion of poor students in colleges and universities is gradually increasing, and the funding management work in colleges and universities has become a focus of college student management. On the basis of obtaining the basic information of students in the poor student database, all colleges and universities can acquire students' achievement information, award information, canteen consumption information, online consumption information, mental health status, activity participation information, and daily life information in the big data platform, combine associated information such as students' family composition, family health status, family income, poverty certificate, and received funding condition, and develop targeted mental health education and skill training for poor students, to provide a basis for accurate assistance and funding decision making.

\section{Strengthening the Management on Employment and Entrepreneurship Education by Using Big Data Technology}

In terms of student employment and entrepreneurship education, employment sectors in colleges and universities may acquire information such as students' native place, major, academic achievement, participation in skills training, skill certificate, career interest, employment region intention, practical experience and entrepreneurial intention, and look for the relevance among this information. At the same time, they can acquire employment industry, region, salary level, employment satisfaction and other information of previous graduates for reference, and offer targeted and strong practical career planning course, employment guidance course, innovation and entrepreneurship education course. Under the premise of conditions, they provide some graduates with personal career planning counseling and entrepreneurship project incubation guidance, and help students establish a correct outlook on career and employment, and help students better go out of campus and step into society.

\section{CONCLUSION}

The advent of big data era not only provides decisionmaking basis for college student management, but also brings opportunities for college management departments' mastering ideological trend of college students, establishing an effective mechanism for student management, and promoting the accuracy and scientificity of college student management. Certainly, there are several problems in colleges and universities, such as changes in the environment of college student management, difficulties in the collection of big data technology information, hidden dangers of big data information security management, and difficulties of big data technology in temporarily meeting the individual needs, which also tests the coping capacity of various student management departments in colleges and universities. In the future, student management departments in colleges and universities can strengthen students' ideological education, establish an early warning mechanism, carry out precise funding, and strengthen the management on employment and entrepreneurship education by means of big data technology, so that college student management can reach a new high.

\section{REFERENCES}

[1] Ding Jian. On the Promotion Effect of Big Data on Government 2.0 [J]. China Information Times, 2012 (9), 12-14.

[2] Dong Huiqin. Challenges and Countermeasures of College Students' Archives Management in Big Data Era [J]. Lantai World, 2017 (20), 3133.

[3] Wang Jing. Analysis on the Challenges and Countermeasures of College Students Management in Big Data Era [J]. Ideological and Political Education Research, 2014, 30 (02), 128-130. 